\title{
Kontribusi Jumlah Pengunjung Obyek Wisata Dataran Tinggi Dieng Bagi Pendapatan Asli Daerah Kabupaten Wonosobo
}

\author{
Adi Kurniawan Sujatmiko', Andryan Setyadharma ${ }^{2}$ \\ ${ }^{1,2}$ Dosen Fakultas Ekonomi, Universitas Negeri Semarang
}

Received: Juni 2019; Accepted: Juli 2019; Published: September 2019

\begin{abstract}
Abstrak
Desentralisasi menyebabkan setiap pemerintah daerah berupaya keras meningkatkan perekonomian daerahnya sendiri termasuk meningkatkan perolehan Pendapatan Asli Daerah (PAD). Bagi suatu daerah yang terbatas potensi sumber daya alamnya akan menjadi tantangan tersendiri dalam upaya untuk memaksimalkan potensi yang dimiliki oleh daerah. Salah satu upaya untuk meningkatkan penerimaan daerah yaitu dengan mengoptimalkan potensi dalam sektor pariwisata. Jenis data yang digunakan dalam penelitian ini adalah data sekunder yang diantaranya mengenai jumlah pengunjung, Indeks harga konsumen, Dana Alokasi Umum, dan Pendapatan Asli Daerah Kabupaten Wonosobo. Alat analisis yang digunakan adalah analisis regresi dengan uji statistik dan uji asumsi klasik. Penelitian ini bertujuan untuk mengetahui pengaruh jumlah pengunjung, Indeks harga konsumen, dan Dana Alokasi Umum terhadap Pendapatan Asli Daerah Kabupaten Wonosobo periode 2015 - 2017. Hasil pengolahan regresi model jangka pendek menunjukan bahwa variabel indeks harga konsumen berpengaruh signifikan terhadap Pendapatan Asli Daerah dengan nilai probabilitas sebesar 0.0090 lebih kecil dari taraf nyata $\alpha=5 \%$. Sedangkan variabel jumlah pengunjung dan Dana Alokasi Umum tidak berpengaruh signifikan terhadap Pendapatan Asli Daerah dengan nilai probabilitas lebih besar dari taraf nyata $\alpha=5 \%$. Sedangkan hasil pengolahan regresi model jangka panjang menunjukan bahwa variabel jumlah pengunjung, indeks harga konsumen, dan Dana Alokasi Umum tidak berpengaruh signifikan terhadap Pendapatan Asli Daerah dengan nilai probabilitas lebih besar dari taraf nyata $\alpha=5 \%$.
\end{abstract}

Kata kunci: pendapatan asli daerah, dana alokasi umum, kunjungan wisata

\begin{abstract}
Decentralization causes every local government strive to improve the economy of the region itself including increasing regional revenue. For a region with limited potential of its' natural resources it will be a challenge in an attempt to maximize the potential of the region. One of the effort to maximize the regional revenue is by optimizing potential in the tourism sector. Types of data in this research are secondary data such as tourist numbers, consumer price index, General Allocation Grant, and Local Revenue of Wonosobo Regency. The analytical tool is multiple regression analysis with statistical tests and classical assumption. This research aimed to understand the effect of the number of visits tourist, consumer price index, and General Allocation Grant against the Local Revenue of Wonosobo Regency from 2015 to 2017. The results of the regression processing of short-term models show that the consumer price index variable has a significant effect on Regional Original Income with a probability value of 0.0090 smaller than the real level $\alpha=5 \%$. While the variable number of visitors and General Allocation Funds did not have a significant effect on Regional Original Income with a probability value greater than the real level $\alpha=5 \%$.
\end{abstract}

Keywords: Local Revenue, general allocation grant, tourism

How to Cite: Sujatmiko, A.K., Setyadharma, A. (2019). Kontribusi Jumlah Pengunjung Obyek Wisata Dataran Tinggi Dieng Bagi Pendapatan Asli Daerah Kabupaten Wonosobo. JFRES: Journal of Fiscal and Regional Economy Studies, 2 (2), 26 - 33.

Corresponding author:

E-mail: andryan@mail.unnes.ac.id 


\section{PENDAHULUAN}

Pembangunan daerah sebagai bagian integral dari pembangunan nasional tidak bisa dilepaskan dari prinsip otonomi daerah. Sebagai daerah otonom, daerah mempunyai kewenangan dan tanggung jawab menyelenggarakan kepentingan masyarakat berdasarkan prinsip keterbukaan, partisipasi masyarakat dan pertanggungjawaban kepada masyarakat. Penerapan otonomi daerah yang luas bertujuan untuk mengembangkan seluruh potensi ekonomi yang ada sehingga dapat memacu peningkatan aktivitas perekonomian di daerah yang pada akhirnya meningkatkan perekonomian nasional (Pujiati, 2007). Untuk mendukung penyelenggaraan otonomi daerah diperlukan kewenangan yang luas, nyata, dan bertanggung jawab di daerah secara proporsional dan berkeadilan, jauh dari praktik-praktik korupsi, kolusi, dan nepotisme serta adanya perimbangan antara keuangan pemerintah pusat dan daerah. Melalui otonomi diharapkan daerah akan lebih mandiri dalam mentukan seluruh kegiatanya dan pemerintah pusat diharapkan tidak terlalu aktif mengatur daerah (Widjaja, 2007).

Pemerintah daerah diharapkan semakin mandiri, karena mempunyai keleluasaan untuk meningkatkan kreativitas dalam mengembangkan potensi yang ada, serta dapat mengurangi ketergantungan terhadap pemerintah pusat bukan hanya dalam pembiayaan tetapi juga terkait dengan pengelolaan penerimaan dan pengeluaran daerah atau desentralisasi fiskal. Desentralisasi fiskal tidak akan berguna jika tidak diikuti dengan kemampuan finansial yang cukup memadai oleh pemerintah daerah (Pujiati, 2007). Sumber penerimaan daerah dalam pelaksanaan desentralisasi berasal dari Pendapatan Asli Daerah (PAD) yang komponennya terdiri dari penerimaan yang berasal dari pajak daerah, retribusi daerah, hasil pengelolaan kekayaan daerah yang dipisahkan dan lain-lain pendapatan yang sah (Widjaja, 2007). Salah satu upaya untuk meningkatkan penerimaan daerah yaitu dengan mengoptimalkan potensi dalam sektor pariwisata. Usaha memperbesar pendapatan asli daerah, maka program pengembangan dan pendayagunaan sumber daya dan potensi pariwisata daerah diharapkan dapat memberikan sumbangan bagi pembangunan ekonomi. Pemerintah telah menargetkan wisatawan mancanegara pada tahun 2019 sebanyak 20 juta orang (Kementerian Pariwisata, 2016). Lebih lanjut lagi, Kementerian Pariwisata menyatakan untuk mengejar target jumlah wisatawan asing pemerintah memprioritaskan 10 destinasi wisata yang disebut sebagai Bali baru. Istilah Bali baru hanyalah kiasan dan dimaksudkan untuk memberi dorongan agar 10 destinasi wisata itu memiliki performa yang sama dengan Bali dalam menarik kunjungan wisatawan asing, dikarenakan Bali adalah ikon pariwisata Indonesia sekitar 40 persen wisatawan mancanegara masuk ke Indonesia melalui Bali. Sepuluh destinasi pariwisata yang menjadi prioritas pemerintah tersebut antara lain: Danau Toba, Belitung, Tanjung Lesung, Kepulauan Seribu, Candi Borobudur, Gunung Bromo, Mandalika Lombok, Pulau Komodo, Taman Nasional Wakatobi, dan Morotai yang berada di Maluku Utara (Kementerian Pariwisata, 2016). Lebih lanjut kementerian BUMN juga menyusun roadmap pengembangan pariwisata Jogja Solo Semarang (Joglosemar), dan akan membagi delapan klaster guna mendongkrak kunjungan wisatawan di daerah tersebut. Pengembangan destinasi wisata itu meliputi klaster Borobudur dan sekitarnya, Jogja dan sekitarnya, Solo dan sekitarnya, Semarang dan sekitarnya. Ditambah dengan klaster Prambanan, klaster Sangiran dan klaster Dieng (Kementerian BUMN, 2016).

Dalam rencana pembangunan jangka menengah daerah Provinsi Jawa Tengah. Pada bidang pariwisata pemerintah daerah akan menyusun program pengembangan kawasan destinasi wisata unggulan yang terdiri dari klaster Dieng, Borobudur, Nusakambangan, dan Karimunjawa. Juga pengembangan kawasan peruntukan pariwisata, yang meliputi koridor (1) Borobudur, Prambanan, Surakarta; (2) Koridor Borobudur, Dieng; (3) Koridor Semarang, Ambarawa, Salatiga; (4) Koridor Batang, Pekalongan, Pemalang, Tegal, Brebes; (5) Koridor Cilacap, Banyumas, Purbalingga, Banjarnegara, serta (6) koridor Cilacap, Kebumen, Purworejo (Peraturan Daerah Provinsi Jawa Tengah No 5 Tahun 2014). Salah satu obyek wisata unggulan yang masuk ke dalam roadmap pengembangan pariwisata adalah obyek wisata Dataran Tinggi Dieng. Dataran Tinggi Dieng merupakan kawasan vulkanik aktif di Provinsi Jawa Tengah, Yang masuk wilayah Kabupaten Wonosobo dan Kabupaten Banjarnegara. Kawasan Wisata Dataran Tinggi Dieng terletak di atas ketinggian 2.000 DPL, mempunyai jarak sekitar $26 \mathrm{~km}$ dari pusat kota Wonosobo. Obyek wisata yang 
terdapat di kawasan wisata Dataran Tinggi Dieng cukup beragam, mulai dari telaga, gua, candi dan Dieng plateau teater.

Kawasan Dataran Tinggi Dieng merupakan obyek wisata andalan Kabupaten Wonosobo, yang diharapkan mampu memberikan kontribusi lebih bagi pendapan asli daerah. Kawasan Dataran Tinggi Dieng merupakan obyek wisata dengan jumlah wisatawan tertinggi di setiap tahunnya, bila dibandingkan dengan obyekobyek wisata lain yang ada di Kabupaten Wonosobo (Disparbud Kabupaten Wonosobo, 2016). Berikut adalah jumlah wisatawan yang berkunjung ke kawasan wisata Dataran Tinggi Dieng di Kabupaen Wonosobo:

Berdasarkan tabel 1 dapat dilihat bahwa pada ke empat obyek wisata Dataran Tinggi Dieng jumlah pengunjung cenderung mengalami peningkatan pada bulan Juli sampai dengan bulan Desember bila dibandingkan pada bulan sebelumnya yaitu pada bulan januari sampai dengan bulan Juni. Obyek wisata dieng plateau teater merupakan obyek wisata dengan jumlah pengunjung paling tinggi dari tahun 2015 sampai dengan tahun 2017 bila dibandingkan dengan obyek wisata lain, sedangkan obyek wisata telaga menjer merupakan obyek wisata dengan jumlah pengunjung terendah dari tahun 2015 sampai dengan tahun 2017. Bila digabungkan ke empat obyek wisata tersebut mengalami peningkatan yang cukup signifikan pada tahun 2016 dengan jumlah total 893.698 wisatawan dari tahun sebelumnya dengan jumlah total 648.192 wisatawan, dan mengalami sedikit penurunan pada tahun 2017 dengan jumlah total 854.045 wisatawan.

Tabel 1. Jumlah Wisatawan Obyek Wisata Dataran Tinggi Dieng Kabupaten Wonosobo Tahun 2015-2017

\begin{tabular}{|c|c|c|c|c|c|c|c|c|c|c|c|c|}
\hline \multirow[t]{3}{*}{ Bulan } & \multicolumn{12}{|c|}{ Jumlah Wisatawan (Jiwa) } \\
\hline & \multicolumn{3}{|c|}{ Kawasan DT. Dieng } & \multicolumn{3}{|c|}{ Lembah Dieng } & \multicolumn{3}{|c|}{ Telaga Menjer } & \multicolumn{3}{|c|}{ Dieng Plateau Teater } \\
\hline & 2015 & 2016 & 2017 & 2015 & 2016 & 2017 & 2015 & 2016 & 2017 & 2015 & 2016 & 2017 \\
\hline Januari & 11900 & 23600 & 37220 & 12695 & 17485 & 37220 & 2658 & 4449 & 1815 & 13205 & 25700 & 37220 \\
\hline Februari & 8100 & 11000 & 16341 & 5792 & 10373 & 16341 & 1527 & 1379 & 1295 & 9125 & 12450 & 16341 \\
\hline Maret & 9050 & 11500 & 13989 & 6328 & 8655 & 13989 & 1675 & 1455 & 1317 & 10020 & 13150 & 13989 \\
\hline April & 8850 & 9000 & 16003 & 7524 & 7325 & 16003 & 1872 & 1556 & 1616 & 9767 & 10950 & 16003 \\
\hline Mei & 15000 & 27050 & 19695 & 17981 & 18810 & 19695 & 2240 & 1941 & 2646 & 17655 & 30550 & 19695 \\
\hline Juni & 7950 & 6700 & 33100 & 6894 & 4711 & 33100 & 1111 & 927 & 3645 & 9650 & 7670 & 33100 \\
\hline Juli & 50750 & 74570 & 33885 & 34154 & 74570 & 33885 & 4311 & 4089 & 4404 & 52840 & 74570 & 33885 \\
\hline Agustus & 22900 & 25959 & 24820 & 18791 & 25959 & 24820 & 1895 & 2142 & 1591 & 24856 & 25959 & 24820 \\
\hline September & 18600 & 20641 & 18044 & 11930 & 20641 & 18044 & 1945 & 2095 & 2166 & 20799 & 20641 & 18044 \\
\hline Oktober & 12800 & 16730 & 15166 & 11779 & 16730 & 15166 & 2251 & 1754 & 1959 & 14150 & 16730 & 15166 \\
\hline November & 18800 & 13050 & 10520 & 8145 & 13050 & 10520 & 2456 & 1443 & 1282 & 21050 & 13050 & 10520 \\
\hline Desember & 31800 & 52450 & 37132 & 22971 & 52450 & 37132 & 4950 & 3589 & 2564 & 34700 & 52450 & 37132 \\
\hline Jumlah & 216500 & 292250 & 275915 & 164984 & 270759 & 275915 & 28891 & 26819 & 26300 & 237817 & 303870 & 275915 \\
\hline
\end{tabular}

Sumber:Dinas Pariwisata dan Kebudayaan Kabupaten Wonosobo, 2018

Obyek wisata Dataran Tinggi Dieng memiliki potensi yang sangat baik karena merupakan salah satu obyek wisata unggulan di Jawa Tengah. Obyek wisata Dataran Tinggi Dieng merupakan salah satu obyek wisata di Jawa Tengah yang masuk ke dalam rencana pembangunan jangka menengah daerah Provinsi Jawa Tengah pada bidang pariwisata. Tingginya jumlah pengunjung obyek wisata Dataran Tinggi Dieng menandakan bahwa konsumsi masyarakat yang meningkat, tinggi atau rendah barang atau jasa yang di konsumsi masyarakat bisa diukur dengan Indeks Harga Konsumen. Indeks Harga Konsumen yang tinggi berpengaruh terhadap penerimaan Pendapatan Asli Daerah pada bidang pariwisata melalui peningkatan kunjungan wisata. Indeks Harga Konsumen merupakan adalah salah satu indikator ekonomi yang memberikan informasi mengenai ukuran biaya keseluruhan barang dan jasa yang dibeli oleh konsumen. Perhitungan indeks harga konsumen dilakukan untuk merekam perubahan harga beli di tingkat konsumen (purchasing cost) dari sekelompok tetap barang dan jasa yang pada umumnya dikonsumsi masyarakat. IHK digunakan untuk mengamati perubahan dalam biaya hidup sepanjang waktu. Tabel Indeks harga konsumen bulanan nasional dapat dilihat pada tabel 2 .

Berdasarkan tabel 2 dapat dilihat bahwa indeks harga konsumen cenderung mengalami kenaikan setiap bulannya pada tahun 2015 sampai dengan tahun 2017. Indeks Harga Konsumen merupakan salah satu indikator ekonomi yang memberikan informasi mengenai harga barang dan jasa yang 
dibayar. Bila dilihat di dalam tabel Indeks Harga Konsumen yang tinggi menandakan tingginya konsumsi barang atau jasa oleh masyarakat yang akan berpengaruh terhadap penerimaan Pendapatan Asli Daerah pada bidang pariwisata melalui peningkatan kunjungan wisata.

Tabel 2. Indeks Harga Konsumen Bulanan Indonesia Tahun 2015-2017

\begin{tabular}{lccc}
\hline \multicolumn{4}{c}{ IHK Bulanan Indonesia 2015-2017 } \\
\hline \multirow{2}{*}{ Bulan } & \multicolumn{3}{c}{ Tahun } \\
\cline { 2 - 4 } & $\mathbf{2 0 1 5}$ & $\mathbf{2 0 1 6}$ & $\mathbf{2 0 1 7}$ \\
\hline Januari & 118.71 & 123.62 & 127.94 \\
\hline Februari & 118.28 & 123.51 & 128.24 \\
\hline Maret & 118.48 & 123.75 & 128.22 \\
\hline April & 118.91 & 123.19 & 128.33 \\
\hline Mei & 119.50 & 123.48 & 128.83 \\
\hline Juni & 120.14 & 124.29 & 129.72 \\
\hline Juli & 121.26 & 125.15 & 130.00 \\
\hline Agustus & 121.73 & 125.13 & 129.91 \\
\hline September & 121.67 & 125.41 & 130.08 \\
\hline Oktober & 121.57 & 125.59 & 130.09 \\
\hline November & 121.82 & 126.18 & 130.35 \\
\hline Desember & 122.99 & 126.71 & 131.28 \\
\hline
\end{tabular}

Sumber: Badan Pusat Statisstik Tahun 2019

Pengembangan sektor pariwisata merupakan salah satu tugas dari pemerintah khususnya pemerintah daerah untuk bisa meningkatkan pendapatan asli daerah dari sektor unggulan di daerah masing masing. Pemerintah pusat melalui dana alokasi umum memiliki peran untuk membantu melakukan pembangunan di tiap daerah melalui pemerintah daerah yang bersangkutan. lebih lanjut dengan adanya kontribusi dana alokasi umum ke masing-masing daerah memberikan pengaruh secara tidak langsung pada peningkatan penyediaan fasilitas penunjang masyarakat dalam mempermudah kegiatan maupun aktivitas perekonomian termasuk salah satunya meningkatkan pendapatan asli daerah melalui aksesbilitas ke sektor pariwata. Berikut merupakan tabel dana alokasi umum Kabupaten Wonosobo dari tahun 2015 sampai dengan tahun 2017:

Berdasarkan tabel 3 dapat dilihat bahwa dana alokasi umum yang diterima Kabupaten Wonosobo pada tahun 2015 sebesar 748.447.761.000, pada tahun 2016 sebesar 841.407.175.000. Kemudian pada tahun 2017 dana alokasi umum yang diterima Kabupaten Wonosobo yaitu sebesar 826.626.357.000. Dana alokasi umum yang cukup besar diharapkan dapat meningkatan penyediaan fasilitas penunjang masyarakat dalam mempermudah kegiatan maupun aktivitas perekonomian di Kabupaten Wonosobo.

Tabel 3. Dana Alokasi Umum Kabupaten Wonosobo Tahun 2015-2017 (Rupiah)

DAU Bulanan Kabupaten Wonosobo Tahun 2015-2017

\begin{tabular}{lc|cr}
\multicolumn{4}{c}{ DAU Bulanan Kabupaten Wonosobo Tahun 2015-2017 } \\
\cline { 2 - 4 } Bulan & \multicolumn{3}{c}{ Tahun } \\
\cline { 2 - 4 } & $\mathbf{2 0 1 5}$ & $\mathbf{2 0 1 6}$ & $\mathbf{2 0 1 7}$ \\
\hline Januari & 62.370 .646 .750 & 70.117 .264 .580 & 68.885 .529 .750 \\
\hline Februari & 62.370 .646 .750 & 70.117 .264 .580 & 68.885 .529 .750 \\
\hline Maret & 62.370 .646 .750 & 70.117 .264 .580 & 68.885 .529 .750 \\
\hline April & 62.370 .646 .750 & 70.117 .264 .580 & 68.885 .529 .750 \\
\hline Mei & 62.370 .646 .750 & 70.117 .264 .580 & 68.885 .529 .750 \\
\hline Juni & 62.370 .646 .750 & 70.117 .264 .580 & 68.885 .529 .750 \\
\hline Juli & 62.370 .646 .750 & 70.117 .264 .580 & 68.885 .529 .750 \\
\hline Agustus & 62.370 .646 .750 & 70.117 .264 .580 & 68.885 .529 .750 \\
\hline September & 62.370 .646 .750 & 70.117 .264 .580 & 68.885 .529 .750 \\
\hline Oktober & 62.370 .646 .750 & 70.117 .264 .580 & 68.885 .529 .750 \\
\hline November & 62.370 .646 .750 & 70.117 .264 .580 & 68.885 .529 .750 \\
\hline Desember & 62.370 .646 .750 & 70.117 .264 .580 & 68.885 .529 .750 \\
\hline Total & 748.447 .761 .000 & 841.407 .175 .000 & 826.626 .357 .000 \\
\hline Sumber: Dinas Pendapatan Pengelolaan Keugangan
\end{tabular}

Sumber: Dinas Pendapatan Pengelolaan Keuangan dan Kekayaan Aset Daerah Kabupaten Wonosobo 2018

Obyek wisata Dataran Tinggi Dieng memiliki potensi yang sangat baik karena merupakan salah satu obyek wisata unggulan di Jawa Tengah. Obyek wisata Dataran Tinggi Dieng merupakan salah satu obyek wisata di Jawa Tengah yang masuk ke dalam roadmap pengembangan pariwisata jogja Solo Semarang (Joglosemar) dan juga rencana pembangunan jangka menengah daerah Provinsi Jawa Tengah pada bidang pariwisata. Tingginya jumlah pengunjung obyek wisata Dataran Tinggi Dieng menandakan bahwa konsumsi masyarakat yang meningkat, tinggi atau rendah barang atau jasa yang di konsumsi masyarakat bisa diukur dengan Indeks Harga Konsumen. Indeks Harga Konsumen yang tinggi secara tidak langsung akan berpengaruh terhadap penerimaan Pendapatan Asli Daerah pada bidang pariwisata melalui peningkatan kunjungan pariwisata. Beradasarkan uraian latar belakang tersebut, tujuan dari penelitian adalah untuk mengetahui kontribusi jangka pendek dan jangka panjang jumlah pengunjung obyek wisata Dataran Tinggi Dieng terhadap Pendapatan Asli Daerah Kabupaten Wonosobo, untuk mengetahui kontribusi jangka pendek dan jangka panjang indeks harga konsumen terhadap Pendapatan Asli Daerah Kabupaten Wonosobo, untuk mengetahui kontribusi jangka pendek dan jangka panjang Dana Alokasi Umum terhadap Pendapatan Asli Daerah Kabupaten wonosobo.

\section{METODE PENELITIAN}

Penelitian ini merupakan penelitian kuantitatif. Pendekatan kuantitatif adalah penelitian yang 
tidak mementingkan kedalaman data, penelitian kuantitatif tidak terlalu menitikberatkan pada kedalaman data, yang penting dapat merekam data sebanyak-banyaknya dari populasi yang luas (Masyhuri dan Zainuddin, 2008). Data yang digunakan dalam penelitian ini merupakan data sekunder yang diperoleh dari Badan Pusat Statistik, Dinas Pendapatan Pengelolaan Keuangan dan Kekayaan Aset Daerah Kabupaten Wonosobo, Dinas Pariwisata dan Kebudayaan Kabupaten Wonosobo. Jenis data yang digunakan dalam penelitian ini adalah data time series. Data yang digunakan dalam penelitian ini antara lain data Pendapatan Asli Daerah Kabupaten Wonosobo tahun 2015 sampai 2017, data jumlah pengunjung obyek wisata Dataran Tinggi Dieng tahun 2015 sampai 2017, data indeks harga konsumen tahun 2015 sampai 2017, dan data Dana Alokasi Umum Kabupaten Wonosobo tahun 2015 sampai 2017.

Variabel terikat yang digunakan dalam penelitian ini adalah Pendapatan Asli Daerah Kabupaten Wonosobo, sedangkan variabel bebas yang digunakan dalam penelitian ini adalah Jumlah pengunjung obyek wisata Dataran Tinggi Dieng, Laju indeks harga konsumen bulanan nasional dan Dana Alokasi Umum Kabupaten Wonosobo.

\section{HASIL DAN PEMBAHASAN}

Setelah dilakukan pengujian statistik, maka pembahasan dan analisis lebih lanjut dari hasil penelitian adalah sebagai berikut:

Tabel 4. Hasil Uji t-Statistik Jangka Pendek

\begin{tabular}{lrrr}
\hline Variabel & Koefisien & t-Statistic & Probabilitas \\
\hline $\mathrm{C}$ & -0.791574 & -0.913837 & 0.3689 \\
\hline $\mathrm{D}(\mathrm{LJP})$ & -0.002074 & -0.207851 & 0.8369 \\
\hline $\mathrm{D}(\mathrm{LIHK})$ & 1.939420 & 2.814379 & 0.0090 \\
\hline $\mathrm{D}(\mathrm{LDAU})$ & -0.201105 & -0.370570 & 0.7138 \\
\hline $\mathrm{ECT}$ & 0.360274 & 3.096551 & 0.0045 \\
\hline
\end{tabular}

Sumber: Data Sekunder Diolah, 2019

Berdasarkan hasil pengolahan regresi model persamaan jangka pendek dapat dilakukan uji signifikansi secara parsial yang menunjukan bahwa variabel indeks harga konsumen berpengaruh signifikan terhadap Pendapatan Asli Daerah dengan nilai probabilitas sebesar 0.0090 lebih kecil dari taraf nyata $\alpha=5 \%$. Variabel jumlah pengunjung dan Dana Alokasi Umum tidak berpengaruh signifikan terhadap Pendapatan Asli Daerah dengan nilai probabilitas lebih besar dari taraf nyata $\alpha=5 \%$. Sedangkan variabel ECT memiliki pengaruh yang signifikan terhadap nilai Pendapatan Asli Daerah dengan nilai probabilitas sebesar 0.0045 lebih kecil dari taraf nyata $\alpha=5 \%$ sehingga model ECM valid dan dapat digunakan dalam penelitian ini

Tabel 5. Hasil Uji t-Statistik Jangka Panjang

\begin{tabular}{lrrr}
\hline Variabel & \multicolumn{1}{c}{ Koefisien } & \multicolumn{1}{c}{ t-Statistic } & Probabilitas \\
\hline $\mathrm{C}$ & -0.791574 & -0.913837 & 0.3689 \\
\hline LJP & 0.026191 & 1.936442 & 0.0633 \\
\hline LIHK & -0.102739 & -0.958021 & 0.3466 \\
\hline LDAU & 0.276832 & 0.912355 & 0.3697 \\
\hline
\end{tabular}

\section{Sumber: Data Sekunder Diolah, 2019}

Berdasarkan hasil pengolahan regresi model persamaan jangka panjang dapat dilakukan uji signifikansi secara parsial yang menunjukan bahwa variabel jumlah pengunjung, indeks harga konsumen, dan Dana Alokasi Umum tidak berpengaruh signifikan terhadap Pendapatan Asli Daerah dengan nilai probabilitas lebih besar dari taraf nyata $\alpha=5 \%$.

\section{Pengaruh Jumlah Pengunjung terhadap} Pendapatan Asli Daerah

Hasil perhitungan menunjukan dalam model jangka pendek bahwa variabel jumlah pengunjung berpengaruh negatif terhadap Pendapatan Asli Daerah. Hubungan antara variabel jumlah pengunjung terhadap Pendapatan Asli Daerah dalam model jangka pendek adalah tidak signifikan. Sedangkan dalam model jangka panjang variabel jumlah pengunjung berpengaruh positif terhadap Pendapatan Asli Daerah. Hubungan antara variabel jumlah pengunjung terhadap Pendapatan Asli Daerah dalam model jangka panjang adalah tidak signifikan.

Hasil estimasi penelitian ini tidak sesuai dengan hipotesis yang menyatakan bahwa jumlah pengunjung memiliki pengaruh positif dan signifikan terhadap Pendapatan Asli Daerah. Dengan demikian berarti apabila semakin banyak jumlah pengunjung obyek wisata Dataran Tinggi Dieng maka Pendapatan Asli Daerah tidak akan bertambah signifikan. Jumlah pengunjung obyek wisata Dataran Tinggi Dieng sebenarnya mempunyai jumlah yang cukup banyak dan seharusnya bisa berkontribusi lebih bagi Pendapatan Asli Daerah Kabupaten Wonosobo, berdasarkan observasi yang dilakukan oleh penulis pendapatan obyek wisata Dataran Tinggi Dieng tidak terserap dan tersalurkan secara maksimal pada beberapa lokasi obyek wisata seperti sikunir dan gunung prau terdapat penarikan biaya masuk lokasi yang dilakukan oleh masyarakat setempat, selain itu pada pintu masuk utama juga terkadang ada pengunjung 
yang melewati jalan pintas sehingga terhindar dari biaya masuk obyek wisata. Hasil dari penelitian ini sejalan dengan penelitian yang dilakukan oleh Bugis (2013), bahwa jumlah pengunjung tidak memiliki pengaruh yang signifikan terhadap Pendapatan Asli Daerah Provinsi Maluku, penelitian oleh Arraniry (2018), bahwa jumlah pengunjung tidak memiliki pengaruh yang signifikan terhadap Pendapatan Asli Daerah Provinsi Nusa Tenggara Barat.

2. Pengaruh indeks harga konsumen terhadap Pendapatan Asli Daerah

Hasil perhitungan menunjukan dalam model jangka pendek variabel indeks harga konsumen berpengaruh positif terhadap Pendapatan Asli Daerah, sedangkan dalam model jangka panjang variabel indeks harga konsumen berpengaruh negatif terhadap Pendapatan Asli Daerah. Hubungan antara variabel indeks harga konsumen terhadap Pendapatan Asli Daerah dalam model jangka pendek adalah signifikan sedangkan pada model jangka panjang adalah tidak signifikan. Nilai koefisien variabel indeks harga konsumen dalam model jangka pendek sebesar 1,939420. Artinya apabila input indeks harga konsumen mengalami penambahan sebesar $1 \%$ maka akan menyebabkan kenaikan Pendapatan Asli Daerah sebesar 1.939420\%. Dengan demikian berarti apabila input indeks harga konsumen mengalami kenaikan maka Pendapatan Asli Daerah Kabupaten Wonosobo akan bertambah. Indeks harga konsumen merupakan nomor indeks yang mengukur harga rata-rata dari barang dan jasa yang dikonsumsi oleh rumah tangga (household).

Hasil penelitian ini sesuai dengan hipotesis bahwa indeks harga konsumen berpengaruh positif dan signifikan terhadap Pendapatan Asli Daerah. Dengan demikian berarti apabila indeks harga konsumen meningkat maka Pendapatan Asli Daerah akan mengalami peningkatan, pada saat indeks harga konsumen tinggi maka pola konsumsi masyarakat akan mengalami peningkatan yang pengaruhnya ke daerah akan mengalami peningkatan juga karena bila dilihat dari segi pendapatan asli daerah karena barang dan jasa yang dikonsumsi masyarakat meningkat dimana Indeks Harga Konsumen yang tinggi berpengaruh terhadap penerimaan Pendapatan Asli Daerah pada bidang pariwisata melalui peningkatan kunjungan wisata. Hasil dari penelitian ini sejalan dengan penelitian yang dilakukan oleh Lestari (2016), bahwa Indeks
Harga Konsumen memiliki pengaruh yang signifikan terhadap Pendapatan Asli Daerah Kota Samarinda.

\section{Pengaruh Dana Alokasi Umum terhadap Pendapatan Asli Daerah}

Hasil perhitungan menunjukan dalam model jangka pendek bahwa variabel Dana Alokasi Umum berpengaruh negatif terhadap Pendapatan Asli Daerah, sedangkan dalam model jangka panjang variabel Dana Alokasi Umum berpengaruh positif terhadap Pendapatan Asli Daerah. Hubungan antara variabel Dana Alokasi Umum terhadap Pendapatan Asli Daerah dalam model jangka pendek maupun jangka panjang adalah tidak signifikan. Dengan demikian berarti apabila semakin banyak jumlah Dana Alokasi Umum maka Pendapatan Asli Daerah tidak akan bertambah signifikan. Dana Alokasi Umum adalah dana yang dialokasikan pemerintah pusat kepada setiap daerah otonom di Indonesia sebagai dana pembangunan.

Hasil penelitian ini tidak sesuai dengan hipotesis yang menyatakan bahwa Dana Alokasi Umum berpengaruh positif dan signifikan terhadap Pendapatan Asli Daerah. Hal ini disebabkan karena di Kabupaten Wonosobo Dana Alokasi Umum lebih banyak digunakan untuk belanja pegawai yang meliputi gaji, tunjangan, honororium, dan vakasi dibandingkan untuk pembangunan infrastruktur. Dalam hal ini Dana Alokasi Umum tidak begitu berpengaruh terhadap Pendapatan Asli Daerah. Pendapatan Asli Daerah akan tetap berjalan karena variabel pemasukan pendapatan yang lain tidak bergantung dengan adanya Dana Alokasi Umum. Hasil dari penelitian ini sejalan dengan penelitian yang dilakukan oleh Isnaini (2014), bahwa Dana Alokasi Umum tidak memiliki pengaruh yang signifikan terhadap Pendapatan Asli Daerah Kabupaten Tulungagung.

\section{KESIMPULAN}

Berdasarkan uraian-uraian yang telah diungkapkan pada pembahasan, maka dapat diambil beberapa kesimpulan yaitu: variabel jumlah pengunjung berpengaruh negatif dan tidak signifikan terhadap Pendapatan Asli Daerah pada model jangka pendek. Sedangkan pada model jangka panjang variable jumlah pengunjung mempunyai pengaruh positif dan tidak signifikan terhadap Pendapatan Asli Daerah. Selanjutnya, variabel indeks harga konsumen berpengaruh positif dan signifikan 
terhadap Pendapatan Asli Daerah pada model jangka pendek. Sedangkan pada model jangka panjang variabel indeks harga konsumen mempunyai pengaruh negatif dan tidak signifikan terhadap Pendapatan Asli Daerah. 3). Variabel Dana Alokasi Umum berpengaruh negatif dan tidak signifikan terhadap Pendapatan Asli Daerah pada model jangka pendek. Sedangkan pada model jangka panjang variable Dana Alokasi Umum mempunyai pengaruh positif dan tidak signifikan terhadap Pendapatan Asli Daerah.

Saran yang diberikan terkait hasil penelitian adalah: 1). Hendaknya pemerintah Kabupaten Wonosobo lebih gencar melakukan program peningkatan dalam promosi pariwisata, meningkatkan fasilitas dan penawaran obyek wisata yang lebih baik, dengan fasilitas yang baik akan mempengaruhi jumlah wisatawan yang berkunjung ke obyek wisata yang berada di Kabupaten Wonosobo. 2). Kerjasama dengan pihak terkait seperti Dinas Kebudayaan dan Pariwisata juga perlu ditingkatkan untuk mengelola dan memperbaiki sarana transportasi publik guna mempermudah akses menuju obyek wisata Dataran Tinggi Dieng. 3). Dalam mekanisme pemungutan retribusi sebaiknya di perbaiki dan pengawasannya agar lebih ketat supaya tidak ada oknum masyarakat yang melakukan pungutan liar di kawasan obyek wisata Kabupaten Wonosobo. 4). Pengalokasian Dana Alokasi Umum dibuat lebih spesifik penggunaannya. Sehingga Dana Alokasi Umum yang diberikan oleh pemerintah pusat bisa digunakan secara optimal sebagai sumber penerimaan yang dapat memacu pertumbuhan ekonomi daerah.

\section{DAFTAR PUSTAKA}

Arraniry, F. (2018). Analisis Pengaruh Sektor Pariwisata terhadap Pendapatan Asli Daerah di Provinsi Nusa Tenggara Barat (Tahun 2012-2016). Skripsi: Universitas Islam Indonesia.

Badan Pusat Statistik. (2019). Data Indeks Harga Konsumen Tahun 2015-2017. Jakarta : Badan Pusat Statistik

Badan Pusat Statistik Provinsi Jawa Tengah. (2017). Data Indeks Kedalaman Kemiskinan Tahun 2015-2017. Semarang: Badan Pusat Statistik.

Berutu, B. (2017). Analisis Faktor-faktor yang Mempengaruhi Pendapatan Asli Daerah di
Kabupaten Pakpak Bharat. Skripsi: Universitas Sumatera Utara.

Bugis, R. (2013). Analisis Faktor-faktor yang Mempengaruhi Peningkatan Pendapatan Asli Daerah Provinsi Maluku Tahun 19902010. Skripsi: Universitas Muhammadiyah Surakarta.

Bank Indonesia. (2016). Indeks Harga Konsumen. Jakarta: Bank Indonesia.

Dinas Pariwisata dan Kebudayaan Kabupaten Wonosobo. (2018). Data Jumlah Pengunjung Obyek Wisata Dataran Tinggi Dieng Tahun 2015-2017. Wonosobo: Dinas Pariwisata dan Kebudayaan Kabupaten Wonosobo.

Dinas Pendapatan Pengelolaan Keuangan Dan Kekayaan Aset Daerah Kabupaten Wonosobo. (2018).

Domai, T. (2011). Sound Governance. Malang: UB Press.

Ghozali, I. (2011). Aplikasi Analisis Multi Variant dengan Program SPSS. Semarang: Badan Penerbit Universitas Diponegoro.

Ghozali, I., \& Ratmono, D. (2013). Analisis Multivariant dan Ekonometrika Teori, Konsep, dan Aplikasi dengan EViews 8. Undip.

Halim, A. (2004). Akuntansi Keuangan Daerah. Jakarta: Salemba Empat.

Isnaini, A. W. (2014). Studi Potensi Ekonomi Sektor Pariwisata Terhadap Pendapatan Asli Daerah Kabupaten Tulungagung. Skripsi: Universitas Brawijaya.

Kementerian Badan Usaha Milik Negara Republik Indonesia. 2016. Rencana Strategis 20152019.

Kementerian Pariwisata. 2016. Pembangunan Destinasi Pariwisata Prioritas 2016-2019.

Lestari, D. (2016). Faktor-faktor yang Mempengaruhi Pendapatan Asli Daerah Kota Samarinda. E-jurnal Universitas Tarumanegara, 642651

Masyhuri \& Zainuddin. (2008). Metodologi Penelitian Pendekatan Praktis dan Aplikatif. Bandung: PT Refika Aditama.

Pemerintah Republik Indonesia. 1974. Undangundang Nomor 5 Tahun 1974, Tentang Pokok-pokok Pemerintahan di Daerah. Jakarta.

Pemerintah Republik Indonesia. 2004. Undangundang Nomor 32 Tahun 2004, Tentang Pemerintahan Daerah. Jakarta. 
Pemerintah Republik Indonesia. 2004. Undangundang Nomor 33 Tahun 2004, Tentang Perimbangan Keuangan antara Pemerintah Pusat dan Daerah. Jakarta.

Pemerintah Republik Indonesia. 2009. Undangundang Nomor 10 Tahun 2009, Tentang Kepariwisataan. Jakarta.

Peraturan Daerah Provinsi Jawa Tengah Nomor 5 Tahun 2014. Tentang Rencana Pembangunan Jangka Menengah Daerah Provinsi Jawa Tengah Tahun 2013-2018.

Pujiati, Amin. (2007). Analisis Pertumbuhan Ekonomi Di Karesidenan Semarang Era Desentralisasi Fiskal. Jurnal Ekonomi dan Bisnis, Vol.12 No.3, Desember 2007 : Hal 61-70.

Purwanti, N. D. (2013). Pengaruh Kunjungan Wisatawan terhadap Pendapatan Asli Daerah Kabupaten Mojokerto. Skripsi: Universitas Negeri Surabaya.

Qaddarochman, N. (2010). Analisis Penerimaan Daerah Dari Sektor Pariwisata di Kota Semarang dan Faktor-Faktor yang Mempengaruhinya. Skripsi: Universitas Diponegoro Semarang.

Rosidin, U. (2010). Otonomi Daerah dan Desentralisasi. Bandung: Pustaka Setia.

Rozikin, M. K. (2015). Pengaruh jumlah kunjungan wisatawan dan jumlah hotel terhadap pendapatan asli daerah di Pulau Lombok. Skripsi: Universitas Muhammadiyah Yogyakarta.

Santosa, B. (2013). Pengaruh Pendapatan Asli Daerah dan Dana Perimbangan Daerah terhadap Pertumbuhan, Pengangguran dan Kemiskinan 33 Provinsi di Indonesia. Jurnal Ekonomi Dan Bisnis Vol. 5, No. 2Juli 2013.

Saparuddin. (2017). Pengaruh Penerimaan Pajak Hiburan dan Inflasi Terhadap Pendapatan Asli Daerah Kota Medan. Skripsi: Universitas Islam Negeri Sumatera Utara.

Suastika, I. Y., \& Yasa, I. M. (2015). Pengaruh Jumlah Kunjungan Wisatawan, Lama Tinggal Wisatawan dan Tingkat Hunian Hotel terhadap Pendapatan Asli Daerah dan Kesejahteraan Masyarakat pada Kabupaten/Kota di Provinsi Bali. E-Jurnal EP Unud, 1332-1363

Suwantoro, G. (2004). Dasar-dasar Pariwisata. Cetakan Keempat. Yogyakarta: Andi.

Wahab, S. (2003). Manajemen Kepariwisataan. Jakarta: Pradnya Paramita.
Widarjono, A. (2007). Ekonometrika: Teori dan Aplikasi Untuk Ekonomi dan Bisnis. Yogyakarta: Ekonisia.

Widjaja, H. (2007). Otonomi Daerah dan Daerah Otonom. Jakarta: PT Raja Grafindo Persada.

Wijaya, I. B., \& Sudiana, I. K. (2016). Pengaruh Jumlah Kunjungan Wisatawan, Penerimaan Pajak Hotel, Restoran dan Pendapatan Retribusi Obyek Wisata terhadap Pendapatan Asli Daerah di Kabupaten Bangli Periode 2009-2015. E-Jurnal EP Unud, 1384-1407 